\title{
Intelligent Technology Scanning: Aims, Content, and Practice
}

\author{
Bradford Ashton \\ Principal Advisor for Technology Management, ashtonwb@ctc.com \\ Concurrent Technologies Corporation, 100 CTC Drive, Johnstown, PA 15904-1935
}

\begin{abstract}
I $\mathrm{n}$ business or government operations, surprise is rarely a good thing. Although sometimes positive, the effects of unexpected events and developments can take a variety of difficult forms - from being simply inconvenient to disastrous. However, foreseeing the future accurately is a difficult process, especially futures that involve dealing with emerging technologies. Further, unexpected new technology developments can produce significant surprises.

The main response to this uncertainty is to establish early warning systems that help anticipate technological surprises. However, many specific internal company early warning efforts set up to anticipate technological surprises are often not effective. Even when successful, early warning alerts can end up not being enough. Not only are responsive actions by

managers essential to dealing with potential surprises, but real benefits can occur when a future technology warning is turned into a company advantage through deliberate actions that arise from the warning process. Incorporating the full set of technology intelligence (TI) practices is an important element of creating a business edge by managing and potentially exploiting surprises.

This paper provides an overview of technology intelligence (TI) as practiced by many organizations today, from the private, government, and international sectors. The discussion begins with describing TI objectives and the TI process and then presents several elements of how TI operations are conducted by focusing on TI customers, descriptions of TI needs, and how to address them.
\end{abstract}

Keywords: technology intelligence; technology; innovation; competitive intelligence; business analytics; competitive advantage; SWOT analysis
Citation: Ashton B. (2020) Intelligent Technology Scanning: Aims, Content, and Practice. Foresight and STI Governance, vol. 14, no 3, pp. 15-29. DOI: 10.17323/2500-2597.2020.3.15.29 


\section{Technology Intelligence Tasks}

All companies apply some form of technology - for product design and testing, manufacturing and production, information and communication, materials and product delivery, and research and development. "Technology" generally refers to the methods, skills, systems, and devices that apply scientific knowledge for practical purposes to improve capabilities, performance, or lower cost. Technologies enable the processes by which an organization transforms labor, capital, materials, and information into products and services of greater value. Naturally, computer and information improvements have technology at their core. Even a retailer like Sears uses its own particular technology to procure, present, sell, and deliver products to its customers, while a discount warehouse retailer like Walmart employs a different set of technologies. The concept of technology even extends beyond manufacturing and engineering to encompass a range of marketing, investment, and managerial processes.

\section{Exploding Information}

Along with business and market data, science and technology (S\&T) information is increasingly important to business and is increasingly prevalent and accessible worldwide. The size, variety, and pace of new technology information available today is difficult to track and understand, especially considering hidden sources like the "deep" and "dark" web. This expanding resource leads to important difficulties in using current information, such as: information overload, unclear accuracy (the reliability of information and the sources from which it comes are often not known), and, consequently, rising search frustration.

Information is the currency of business operations, but the exploding, dynamic, and complex information environment often makes it difficult to find what you want, when you want it, in the format you need, and at the confidence level you require to use it, which can also lead to technological surprises. As John Naisbitt (1982) stated some time ago, "We are drowning in information but starved for knowledge" [Naisbitt, 1982]. A fundamental response to this situation is to build and apply technology intelligence (TI) systems.

These systems are a specialized version of competitive intelligence (CI) practices [Calof et al., 2010, 2015] with a focus on technological issues. TI addresses organizational needs for technology information - to identify the technological opportunities, threats, and situations that could impact the survival of the company and future business growth. TI aims to capture, interpret, and disseminate the technological information needed within an organization to support strategic planning, investments, and operations. TI provides results that serve as insurance to help ensure that any organization stays competitive.

\section{Technology Intelligence (TI) Defined}

Most TI "best practice" firms have a shared, widely understood definition of TI that is captured using basic concepts such as:

TI is analytical information about external scientific or technological activities, developments or organizations that have the potential to affect an establishment's shortor long-term competitive situation [Ashton, Klavans, 1997].

TI is a special form of information; it is created by collecting, processing, and analyzing raw data - intelligence is not simply "collected." Like CI, the TI process begins with a collection plan, gathers input data, validates, and then evaluates these data to produce intelligence results and findings. Although TI inputs are expected to be obtained using legal and ethical methods, employing these practices is not always the case, as in for example industrial espionage, insider trading, or "information swapping". This paper reinforces legal and ethical practices that are implemented to address established consumer "intelligence needs" or questions in a current, timely, and appropriate way. Effective TI can be described as:

- Analytical - It has been processed, interpreted, and validated as accurate

- Actionable - It answers the question, "So What?" (Is the intelligence useful and why?)

- Protected - It is controlled to prevent inadvertent disclosure

For a perspective on TI that is based on everyday experience, TI actions and procedures can be understood by considering their similarity to several analogous actions, as shown in Table 1. Building on what is meant by TI, Table 1 also informs on what TI is NOT.

As an example, to illustrate intelligence concepts, Table 2 shows two descriptions of a company report on recent market activity. They illustrate the company response to a market situation.

With more detail and insights in the report, it should be clear that the second response is the superior one. The strength of intelligence reports is that they include components for a timely, effective, and focused response: custom-tailored reports for multiple users, possible early warning, identified and verified sources, explicit interpretation and action recommendations [Fleisher, Ashton, 2009]. This points to the fundamental principle that intelligence is "deliberately produced, not just collected."

\section{Effective TI Is a Force Multiplier}

TI products can reveal significant technical and business opportunities for an enterprise, but the effort must be well-organized, use effective means to gather and analyze information, and convey the intelligence to customers who can act upon it by employing trained individuals with experience, skills, and the right temperament. Many companies operate ongoing TI efforts 
and gain multiple types of advantages for their business [Manzini, Mariotti, 2009]. The comprehensive published literature covering TI contains numerous valuable resources to enhance knowledge of current practices and benefits. For example, Shell Oil Company uses TI in their strategic business planning [Narajulah, 2009] and Daimler Benz Aerospace has successfully used scenario analysis and early warning [Tessun, 2007]. Other companies are highlighted in [Norling et al., 2000] of DuPont, including Motorola, SmithKline Beecham, Clorox, and Baxter Health Care. TI is also used as part of company R\&D efforts as described for $3 \mathrm{M}$ and Proctor and Gamble [Buzzanga, 2008] and, increasingly, companies integrate TI into their efforts to implement open innovation [Veugelers et al., 2010].

TI also includes the growing business practice of technology scouting (TS), which refers to systematically searching and/or partnering to identify attractive external technologies that can be acquired to improve a firm's operations and competitive position. Deutsche Telekom has been active in technology scouting for many years and this has led numerous new technologies of interest [Rohrbeck et al., 2007]. Technology scouting has become a valuable element of an open innovation approach to new technology acquisition, among other applications, for a variety of technology-based firms. The value lies in both strengthening current businesses and identifying future growth opportunities. Successful in-house technology scouting programs, where companies have identified and exploited specific external technologies, include firms such as Northrop Grumman, Dow Chemical, Saudi Aramco Energy Ventures, W.L. Gore \& Associates, Vulcan Labs, and the National Science Foundation's Small Business Innovation Research (SBIR) program. ${ }^{1}$ For example, the Owens Corning Front End of Innovation Group identified and pursued external technologies in the advanced materials areas such as polymer modified asphalt, smart materials, binders, and 3-D polymers. Within 18 months, this effort eventually led to the development of XSTRAND, a high performance 3-D printable platform, with commercial grade sales in Q2 2017.

\section{TI Needs in Industry and Government}

All forms of intelligence begin with an understanding of customer needs for intelligence - what information customers require about their environment, current position, and/or future prospects. Commercial and government customers alike have both common and unique intelligence needs concerning current and emerging technologies. The TI needs of these customers concern topics for which accurate, timely, and validated information is important. Intelligence needs can cover a wide range of technology-related topics including competitor's technology status along with progress on emerging technologies and, more generally, public and private $\mathrm{R} \& \mathrm{D}$ funding for advanced development and imported manufacturing methods by industry players.

\section{Specifying Intelligence Needs}

Above all, the time horizon for intelligence needs must be clarified, as appropriate, to cover both short-term purposes (days or weeks) and also long-term requirements (weeks, months, or even longer). The shortterm focus covers situations where, say, a new product announcement is expected within weeks, while longerterm needs would arise when a new, faster production investment is being made for implementation after development work over the next few months or years.

Then, the level and scope of particular TI needs can also vary - from tactical needs with limited, focused scope, such as assessing the factory production cost for current production systems, to more high-level strategic/general needs, such as understanding the market impact of large-scale technology investments over many competitor manufacturing locations.

\section{Types of TI Needs}

Technology intelligence needs involve technology-related topics, including technology organizations and government S\&T programs. Several typical types of needs for current and accurate intelligence, which can be either general or specific depending on the circumstances, are described in Table 3.

\section{TI Applications and Products}

There are three broad objectives for TI efforts and more specific example TI applications that are shown in Table 4. Many more specific applications have been carried out using TI (see for example [Ashton, Stacey, 1995; Ashton, Klavans, 1997; Mortaraet al., 2010; Manzini, Nasullaev, 2017].

\section{Table 1. Activities Related and Unrelated to TI}

\begin{tabular}{|l|l|}
\hline Related & - Journalism - Investigative reporting \\
activities & $\begin{array}{l}\text { - Law enforcement - Detective work } \\
\text { - Scientific research - Creating/finding } \\
\text { new fundamental knowledge (theories, } \\
\text { principles) about the world }\end{array}$ \\
& $\begin{array}{l}\text { - Gaming - Figuring out the angle to win at } \\
\text { competitive contests }\end{array}$ \\
& $\begin{array}{l}\text { - Puzzles - Completing difficult puzzles } \\
\text { rapidly }\end{array}$ \\
\hline $\begin{array}{l}\text { Unrelated } \\
\text { activities }\end{array}$ & $\begin{array}{l}\text { - Spying } \\
\text { - Simple database searches }\end{array}$ \\
& $\begin{array}{l}\text { - Rumors/ propaganda found on the internet } \\
\text { - A crystal ball } \\
\text { - Found in software packages alone }\end{array}$ \\
\hline Source: author.. & \multicolumn{2}{|l}{} \\
\hline
\end{tabular}

\footnotetext{
http://lanode.org/technology-scouting-workshop-2016/technology-scouting-workshop-speakers/

https://www.marketwatch.com/press-release/owens-corning-to-showcase-the-power-of-composites-to-make-impossible-things-at-jecworld-2018-2018-03-05
} 


\section{Table 2. Company Responses to a Market News Situation}

\begin{tabular}{|l|l|}
\hline $\begin{array}{l}\text { Background news } \\
\text { item }\end{array}$ & $\begin{array}{l}\text { Company A is about to release a new process automation product in two months that is aimed at competing on our } \\
\text { target markets. Early reaction has been that industry observers speculate it will "revolutionize" the market }\end{array}$ \\
\hline \multicolumn{2}{|l|}{ "Information" report } \\
\hline Recipient & Product manager of Company B \\
\hline $\begin{array}{l}\text { Form of } \\
\text { communication }\end{array}$ & Phone call, verbal/ meeting, memo \\
\hline Contents & $\begin{array}{l}\text { Company A is about to release a new automation product in two months. Early reports by industry experts is that it } \\
\text { will revolutionize the market. }\end{array}$ \\
\hline Response & It could be a serious threat to us - we need to call a meeting and decide how to respond to this problem! \\
\hline \multicolumn{2}{|l|}{ "Intelligence" report } \\
\hline Recipient & Product manager (and others) of Company B \\
\hline $\begin{array}{l}\text { Form of } \\
\text { communication }\end{array}$ & Short one-page "alert" message/report \\
\hline $\begin{array}{l}\text { Observation (the } \\
\text { data): }\end{array}$ & $\begin{array}{l}\text { Company A is about to release a new product platform - possibly in six to eight weeks (source: news report, } \\
\text { contacts) }\end{array}$ \\
\hline $\begin{array}{l}\text { Interpretation } \\
\text { (what the data } \\
\text { means): }\end{array}$ & $\begin{array}{l}\text { Preliminary performance data (network contacts) indicate that the new product could disrupt current markets and } \\
\text { draw existing customers away from B within three months of release. }\end{array}$ \\
\hline $\begin{array}{l}\text { Recommendation/ } \\
\text { Action (what } \\
\text { should be done?) }\end{array}$ & $\begin{array}{l}\text { Respond! Call a meeting of R\&D, engineering, marketing, etc. to develop a game plan. Options to consider: } \\
\text { a) retreat and launch R\&D to leapfrog or improve upon As product with upgrades, b) beef up advertising and } \\
\text { compete as long as we can before an exit, c) other options }\end{array}$ \\
\hline Source: author. &
\end{tabular}

TI products fall into one of two basic groups: on the one hand, routine or regular outputs, often on a preset schedule, and on the other hand, specialized products (usually developed on an as-needed basis) addressing specific unique needs with appropriate data and methods of analysis. Examples of both groups are presented in Table 5.

Many TI suppliers have used a structured format to organize findings and back-up evidence. This arrangement of information works well for long TI products or for short one-page deliverables. The format should include a range of topics as shown in Table 6.

\section{The TI Process - How Does the Intelligence Cycle Work?}

The main steps to gather, evaluate, and produce intelligence comprise the Intelligence Cycle. Many articles describe the basic activities in the process of preparing competitive and technology intelligence (e.g. [Ashton, Klavans, 1997; Brenner, 2009; Mortar et al., 2010, Manzini, Nasullaev, 2017]. As shown in Figure 1, the process usually includes five inter-related steps to add value to original inputs and create a substantially transformed product. The overall purpose of this process is for the intelligence service to provide customers/decision makers with "products" containing insights that assist them in understanding their environment along with insights on the threats, opportunities, and developments it contains. Although the process is multidimensional and multidirectional, the steps form a feeback loop which is implemented in an interactive and iterative manner. Figure 1 indicates that the TI process loop is closed so that the Delivery and Feedback step satisfies the Customer Needs that initially drove the process. All steps rely upon an organized information, storage, analysis, and communication system that is linked to all the relevant parties in the organization.

\section{Step 1: Customer TI Needs Assessment}

All good intelligence efforts begin with the formulation of a basic intelligence problem or scenario to focus the TI work on important and urgent matters. Intelligence needs are more focused and describe key elements of the intelligence problem. Needs can be expressed by questions such as:

- What are our competitors doing to maintain an edge on the market?

- What kind of equipment was being used on their production line and does it perform better than ours?

\section{Figure 1. TI Process Steps}

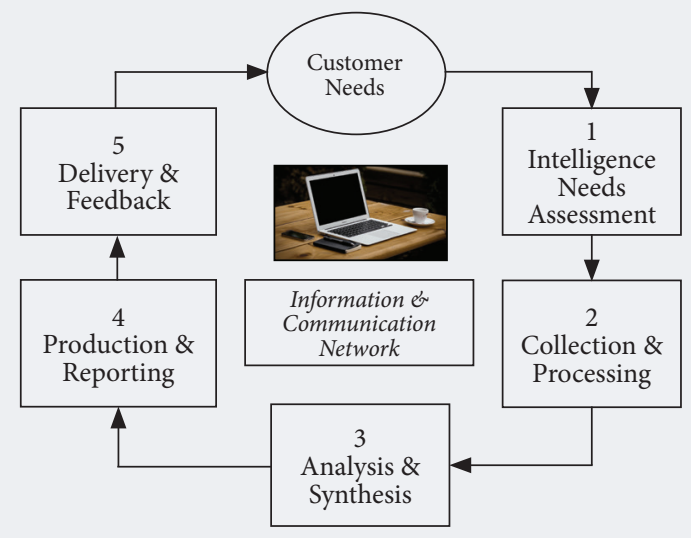

Source: author. 
Table 3. Types of TI Needs

\begin{tabular}{|l|l|}
\hline \multicolumn{1}{|c|}{ Field } & \multicolumn{1}{c|}{ Description } \\
\hline Science & $\begin{array}{l}\text { Identify and track new fundamental knowledge, potential new players/ capabilities or possible breakthrough } \\
\text { developments, such as new drug compounds being developed by pharmaceutical companies }\end{array}$ \\
\hline Technology & $\begin{array}{l}\text { Assess current production system equipment use, emerging technology development progress, potential } \\
\text { disruptive products, new approaches or applications }\end{array}$ \\
\hline $\begin{array}{l}\text { Organizations/ } \\
\text { Companies }\end{array}$ & $\begin{array}{l}\text { Identify key new players, assess their roles (competitor, partner) capabilities, plans, and intentions, assess how } \\
\text { their technology performs, its costs, and the status of ongoing improvements }\end{array}$ \\
\hline $\begin{array}{l}\text { Business Sector } \\
\text { (Market/ Industry) }\end{array}$ & Assess current/future growth prospects for new niche technology markets or key player partnerships \\
\hline S\&T Strategic Issues & $\begin{array}{l}\text { Understand government regulations, public trade/S\&T policies, funding levels, or market attitudes toward } \\
\text { S\&T }\end{array}$ \\
\hline Source: author. & \\
\hline
\end{tabular}

- Where are the competitor's plants located?

- How quickly did the competitor turn out their product?

- What are the potential threats and opportunities on this market that staff should uncover in time to respond?

These and other concerns will drive specific TI collection and analysis efforts.

\section{KITs}

Many organizations identify management's intelligence needs by applying a widely used Key Intelligence Topics (KIT) process and related Key Intelligence Questions (KIQs) [Herring, 1999].

KITs are analytical statements of information needs that identify what content intelligence should provide to organization customers for them to be effective. KITs tend to be long-standing analytically based business and technology concerns. KIQs are specific, usually near-term questions from a specific internal customer or group that can be answered by a directed intelligence operation (collection, analysis, and delivery) - a current, usually high priority intelligence requirement.
TI needs can be organized into three main categories (Table 7).

Examples of these CI KITs can be found in [Herring, 1999] where their use is also discussed. TI staff use the KITs as an essential input to the design of intelligence requirements and collection and analysis plans. In addition, this information enables the identification of the guidelines and methods for the successful dissemination and communication of the intelligence findings to the customers, helping them prepare follow-on actions.

KITs are identified during TI staff interviews with company leaders as well as from documented organization strategy and design and operating practices. They are then documented carefully to ensure agreement among key players and they are reviewed and updated as needed. KITs are a shared responsibility between the customer and the intelligence staff. The interactive dialogues undertaken to identify them provide the focus needed to plan and conduct effective intelligence operations, while permitting CI program designers and managers to determine the resources required to address the company's actual intelligence needs. Best practice TI activities include the following practices for customer needs interviews:

\section{Table 4. TI Objectives}

\begin{tabular}{|c|c|}
\hline Objective & Description \\
\hline $\begin{array}{l}\text { 1. Provide Surveillance - } \\
\text { Awareness and Early } \\
\text { Warning: }\end{array}$ & $\begin{array}{l}\text { Deliver regular updates and "heads up" alerts for upcoming external events or trends, identify and track } \\
\text { new technologies, innovations, and organizations, and then assess: } \\
\text { - Threats } \\
\text { - Opportunities } \\
\text { - Current and future trends }\end{array}$ \\
\hline $\begin{array}{l}\text { 2. Deliver Support for } \\
\text { Operating Decisions and } \\
\text { Actions }\end{array}$ & $\begin{array}{l}\text { Ensure customers get needed day-to-day competitive technology information. } \\
\text { Internal Product and Process Development } \\
\text { - Assess R\&D Technical Approaches } \\
\text { - Review Investment Options } \\
\text { - Accelerate New Product Development } \\
\text { - Focus on Commercial Market Plans } \\
\text { External Organization Postures and Potential Moves } \\
\text { - Identify Business Partnerships } \\
\text { - Conduct Merger / Acquisition Due Diligence }\end{array}$ \\
\hline $\begin{array}{l}\text { 3. Help Implement } \\
\text { Strategy Development and } \\
\text { Planning }\end{array}$ & $\begin{array}{l}\text { Provide planners with long term situation assessments and forecasts, suggesting: ion. } \\
\text { - Competitive Initiatives } \\
\text { - New Market or Customer Strategies }\end{array}$ \\
\hline
\end{tabular}


Table 5. TI Products

\begin{tabular}{|l|l|}
\hline \multicolumn{1}{|c|}{ Example product } & \multicolumn{1}{c|}{ Regular } \\
\hline \multicolumn{2}{|c|}{ Description } \\
\hline Current Alert message & Heads up" message on current events having immediate and serious impacts that require action \\
\hline Technical Newsletter report & Periodic analytical summaries of current technical topics, e.g. an emerging technology \\
\hline Trip or Contact reports & Summary highlights of key findings, results from business or technical discussions \\
\hline Comprehensive Assessments & $\begin{array}{l}\text { In-depth analysis of a major S\&T topic (e.g. competitor long term product investment or an emerging } \\
\text { technology capability from a university research program) }\end{array}$ \\
\hline $\begin{array}{l}\text { Periodic Trade Fairs or } \\
\text { Conference Monitoring }\end{array}$ & Check for developments during key events. \\
\hline \multicolumn{2}{|c|}{ Specialized } \\
\hline Situation analysis & $\begin{array}{l}\text { Snapshot evaluation of external developments with potential positive or negative implications; e.g. a new } \\
\text { regulation or emerging technology }\end{array}$ \\
\hline Strategic Forecasts & Analytical projection of key trends or events (e.g., the growing size of an emerging market niche) \\
\hline Source: author. &
\end{tabular}

- Conduct interviews face-to-face, if possible

- Use two interviewers - to be sure not to miss anything

- Structure the interview topics and scheduled time including: need description; scope and depth of detail; timing; type of activity desired to fill the need

- Remember - customers do not always KNOW their own intelligence needs; needs may require identification through business or technology concerns expressed by the interviewee or external viewpoints

- KITs are dynamic - they may change and should be updated

- Go back to the customer to close the loop during the intelligence operation in case changes or adjustments are needed.

\section{Convert User Needs into Intelligence Requirements}

Intelligence needs are typically expressed as desired information by customers in a particular format and on an expressed timeline. This provides a basis for the specifying the practical intelligence requirements for data sources and content that can be addressed in formalized information collection and analysis plans. Employing a structured approach can help the play- ers avoid inefficiencies and take the first step toward generating clear intelligence requirements by defining both the intelligence problem and the requisite components to its solution. A dialogue about the "Five Ws plus One" - Who, What, When, Where, and Why and How - is a good starting point. Clarifying these issues helps to define the intelligence problem, which is the heart of customer needs. Clarifying these helps one prepare for the next step in the process - developing collection and analysis requirements and plans. In both government and business, these questions form the basic framework for decision makers and TI practitioners to follow in order to create intelligence requirements and devise a strategy to address them.

To understand TI and its component activities, we begin by explaining what TI is designed to produce as outputs, pointing to the main requirements to conduct successful TI operations. Based on a classic, longstanding intelligence source [Krizan, 1999], Table 8 provides an example situation.

\section{Step 2: TI Collection and Processing}

Traditional methods for producing "intelligence" range from manually sifting through publications and journals, networking, or attending tradeshows, organizing

\section{Table 6. TI Report Topics}

\begin{tabular}{|l|l|}
\hline \multicolumn{1}{|c|}{ Item } & \multicolumn{1}{c|}{ Contents/Questions answered } \\
\hline Identification & Topic name, date, author contact \\
\hline $\begin{array}{l}\text { Bottom Line Up Front } \\
\text { (BLUF) }\end{array}$ & Clear statement of the "Bottom Line Up Front" - the important overall message from this TI effort \\
\hline Observations & What are the facts, data and key uncertainties about the observed external situation? \\
\hline Documentation & Data sources; judgment on source reliability and information quality; where to learn more \\
\hline Assumptions & What is assumed to fill in missing facts? \\
\hline Interpretation & What do these observations mean for us? \\
\hline Rationale & Why? What is the basis for the interpretation? \\
\hline Recommendation & So, what? What should we do? Why? \\
\hline Source: author. & \\
\hline
\end{tabular}


Table 7. Key Intelligence Topics

\begin{tabular}{|c|c|c|}
\hline Category & Items & Contents \\
\hline Early-warning topics & $\begin{array}{l}\text { Competitor initiatives, } \\
\text { technological surprise, } \\
\text { product demand shifts, } \\
\text { market changes or } \\
\text { governmental actions }\end{array}$ & $\begin{array}{l}\text { - Tracking the development of emerging technologies using a systematic and } \\
\text { consistent mining of information to provide a heads up for these technologies that } \\
\text { can disrupt one's competitive position, } \\
\text { Early warning of new entrants or departures affecting the competitive space based } \\
\text { on their position and investments in relevant new technologies } \\
\text { Alerts of new technology partnerships that will change the market landscape for } \\
\text { one's products }\end{array}$ \\
\hline $\begin{array}{l}\text { Strategic decisions } \\
\text { and actions }\end{array}$ & $\begin{array}{l}\text { Development of } \\
\text { strategic plans and } \\
\text { strategies }\end{array}$ & $\begin{array}{l}\text { - Evaluating candidates for long-term investment in new capabilities or a new } \\
\text { partnership } \\
\text { - Assessment of the long-term potential for emerging technologies } \\
\text { Detecting and interpreting the often weak, non-obvious signals from technology } \\
\text { or market landscape scans }\end{array}$ \\
\hline
\end{tabular}

focus groups, hiring outsourced consultants, or just surfing the Internet or specialized databases. These methods, even in combination, are useful, but still have a number of drawbacks: it is difficult to identify relevant information, these methods take long periods of time to complete, they are resource-intensive, expensive, and ultimately return unpredictable, often incomplete or inadequate, results. However, by combining internet content, premium scientific and engineering journals, and patent information with "smart" search technology and analysis, a new breed of technology tools allows companies to quickly search and summarize answers that are not available through traditional search methods [Das, 2020]. The key difference here is in the approach and results: this is the first step in cutting information overload and finding solutions to technical and business problems through results that are relevant and have meaning [Buzzanga, 2008].

\section{TI Sources}

Like other forms of competitive and national security intelligence, TI collection uses a variety of sources from which to gather the range of relevant information. Data gathering also employs a variety of approaches, based on the type of source, the focus of the investigation, the role of time constraints and resources avail- able. TI sources used for TI collection fall into four categories summarized in Table 9.

Table 10 shows the basic, broad characteristics of the main types of intelligence sources. The source types are also aligned with national security intelligence terms that are used to label them.

The sources for TI fall into three groups that permit useful comparisons between the use of sources for specific types of input data.

Primary sources can be found both internal to an organization as well as outside on markets or other venues and represent one of the most valuable ways to gather firsthand information. Table 11 lists several specific examples of human sources from which both current and past information can be obtained. Mechanisms for collecting primary information emphasize direct human conversation where interaction and discussion can occur, but, also today, telephone conversations and social media are widely used avenues for communication and therefore, primary collection. In addition, direct observation of intelligence targets, such as inspecting or reverse engineering equipment, is also a primary source collection mechanism.

Reverse engineering is the process by which a manmade object (e.g. equipment or software) is decon-

\section{Table 8. Basic Items of Successful TI Operations}

\begin{tabular}{|l|l|}
\hline \multicolumn{1}{|c|}{ Item } & \multicolumn{1}{c|}{ Description / Answered questions } \\
\hline The Intelligence Problem & Company Y learns that Company X has suddenly reorganized their production department \\
\hline The Intelligence Need & Company Y CEO wants to know why and how Company X changed \\
\hline $\begin{array}{l}\text { The Intelligence } \\
\text { Requirements }\end{array}$ & $\begin{array}{l}\text { - What changed in Company X's production department? } \\
\text { - How large an effort was it - large, fundamental investment or modest equipment and raw material } \\
\text { rearranents? }\end{array}$ \\
\hline \multicolumn{2}{|l|}{ Hource: author's elaboration based on [Krizan, 1999]. } \\
\hline
\end{tabular}


Table 9. Summary of TI Sources

\begin{tabular}{|c|c|}
\hline $\begin{array}{l}\text { Type of } \\
\text { Source }\end{array}$ & Description \\
\hline Primary & $\begin{array}{l}\text { Sources that involve direct interaction with humans or direct observation of items of interest } \\
\text { - Communication (interactions with one or more persons) - Distant contact (e.g. phone) or close contact (face-to- } \\
\text { face) } \\
\text { - Direct Observation - visits, tours, inspection of sites of interest, and "reverse engineering" }\end{array}$ \\
\hline Secondary & Sources that provide processed, documented and published information in hard copy or electronic form \\
\hline Technical & $\begin{array}{l}\text { Sources that use equipment to gather and transmit characteristics of the items being measured (photographs, sample } \\
\text { chemical emissions from a chemical process plant or other imagery) }\end{array}$ \\
\hline Mixed & Documented primary information (reports/summaries). Discussion or meeting recordings \\
\hline
\end{tabular}

structed to reveal its designs, architecture, or to extract knowledge from the object; this is similar to scientific research.

Secondary Sources include both internal and external materials that are publicly distributed and/or available. In addition, secondary sources also include so called "gray literature", which is usually available publicly, but not produced for wide public distribution within commercial or academic distribution channels. Table 12 shows several types of secondary sources, which are also important for competitive or market intelligence.

The third category can be described as Technical Sources, which are typically useful for technical intelligence applications, although at times the information can also aid with competitive or market intelligence. They have some features that overlap with Primary and Secondary sources. As shown in Table 13, most of these sources either produce outputs using specialized equipment that produce engineering measurements or include computerized databases with information on research, engineering, or technology developments.

Tables 11-13 illustrate the vast potential for intelligence information collection from a wide variety of sources. This range provides opportunities for the use of multiple types of sources, or combinations of sources, to obtain unique data or aid with data validation.

\section{Collection Processing}

Usually, the raw collected information is not directly useful for analysis and intelligence production. Information collected from special-source human and technical collection must be processed into "intelligence information" that is usable by analysts and customers. Processing methods to improve the collected data include techniques to clean, organize, and clarify the data, and the addition of comments and interpretative notes that were not documented during collection. These methods will vary depending on the form of the collected information and its intended use (Table 14).

\section{Step 3: Analysis and Synthesis}

Once data are processed and reviewed, intelligence analysis is applied to give context to the data and enable the development of specific intelligence findings and recommendations for customers. The key activities will sometimes overlap with processing work. This includes hypothesizing causes for observations, making comparisons among different aspects of the issue at hand, forecasting events or trends, and assessing impli-

Table 10. Basic Characteristics of the Main Types of Intelligence Sources

\begin{tabular}{|l|l|l|}
\hline \multicolumn{1}{|c|}{ TI Source } & \multicolumn{1}{|c|}{ Description } & \multicolumn{1}{c|}{ Type of Information Available } \\
\hline People (human intelligence/ HUMINT) & $\begin{array}{l}\text { Direct contact with human experts, } \\
\text { eyewitnesses, participants }\end{array}$ & $\begin{array}{l}\text { Firsthand knowledge, referral to other sources } \\
\text { or expert opinion about things like technical } \\
\text { feasibility, major delivery bottlenecks, etc. }\end{array}$ \\
\hline $\begin{array}{l}\text { Records (imagery intelligence/ IMINT } \\
\text { or signals intelligence/ SIGINT) }\end{array}$ & $\begin{array}{l}\text { Symbolic (written reports) or non- } \\
\text { symbolic (images, data logs) }\end{array}$ & $\begin{array}{l}\text { Research, background information, conversion to } \\
\text { useful form such as an electronic or a standardized } \\
\text { format }\end{array}$ \\
\hline Objects (IMINT) & $\begin{array}{l}\text { Physical characteristics of tangible } \\
\text { objects such as equipment, products } \\
\text { (size, shape, markings) }\end{array}$ & $\begin{array}{l}\text { First-hand reporting on composition, condition, } \\
\text { origin, design, functionality or human purpose }\end{array}$ \\
\hline $\begin{array}{l}\text { Emanations (Measurement and } \\
\text { signature intelligence/ MASINT, OR } \\
\text { signals intelligence/ SIGINT) }\end{array}$ & $\begin{array}{l}\text { Detectable phenomena emitted by } \\
\text { natural or man-made objects (heat, } \\
\text { sound, chemical. Electronic or } \\
\text { radiological residues) }\end{array}$ & $\begin{array}{l}\text { Scientific and technical metrics of performance or } \\
\text { features of the target }\end{array}$ \\
\hline Source: [DoD, 2004] & \multicolumn{2}{|l}{} \\
\hline
\end{tabular}


Table 11. Primary Sources

\begin{tabular}{|c|c|}
\hline Category & Items \\
\hline Internal & $\begin{array}{l}\text { - Technical Colleagues } \\
\text { - Technical Networks } \\
\text { - R\&D Managers } \\
\text { - Latekeepers, creative staff } \\
\text { - Legary staff Staff } \\
\text { - Functional Staff (marketing, planning, etc.) }\end{array}$ \\
\hline External & $\begin{array}{l}\text { - Customers } \\
\text { - Technical Colleagues } \\
\text { - Technical Authors } \\
\text { - Suppliers/Vendors } \\
\text { - Trade Association Staff } \\
\text { - Trade Shows, Conferences, Seminars } \\
\text { - Consultants, Industry/Academic } \\
\text { - Exancial/Securities Analysts } \\
\text { - Journalive Recruiters } \\
\text { - Special Interest Groups } \\
\text { - Journal, newsletter editors } \\
\text { - University professors } \\
\text { - Association/society staff } \\
\text { - Expert Panels/Advisory groups }\end{array}$ \\
\hline
\end{tabular}

cations and potential actions for customers in light of the intelligence needs identified earlier in the process.

\section{Analysis Concepts}

Intelligence analysis is the process of reviewing, validating, selecting, synthesizing, and interpreting collected evidence to gain awareness of current situations, explain key activities, and forecast potentially important future developments of interest to stakeholders. The focus in analysis is on results and findings about what is going on and what is likely to happen next addressing the basic questions of the 5 Ws plus One mentioned earlier. These questions frame and define the intelligence problem. Intelligence analysis is an iterative process that involves the application of individual and group cognitive methods and tools to weigh data, build hypotheses, and test them within a practical intelligence problem context [Heuer, 1999]. Analysis usually benefits from a group process since that approach forces the consideration of multiple explanations and interpretations.

One of the most important jobs of an intelligence analyst is determining the veracity of source data and information. Intelligence inputs, especially the peoplebased ones labelled HUMINT, can be fragmentary and of questionable reliability. Much of this information comes from speculation, second-hand rumors, or even can be just plain lies. The process of evaluating data for reliability, validity, and relevance, integrating it, and converting it into a useful processing and analysis inputs is an important element of building confidence in intelligence sources and results. Although intelligence analysis is not a branch of science, it bears some important similarities to scientific work. As in scientific studies, TI analysis involves:
- generating and testing hypotheses to explain source data,

- assessing levels of uncertainty in both the evidence and working conclusions,

- effectively communicating these findings to stakeholders, usually with some form of probabilistic or "level of confidence" statements.

Intelligence analysts focus on certain events, actions, persons, or sources to develop propositions or hypotheses that describe and explain what has been observed; and then use the hypothesis to make predictions about what is likely to subsequently occur. A critical evaluation of the data is done, usually by breaking down a subject into its constituent parts and describing the parts and their relationship to a whole picture. This is especially important for patent data since patents represent current technology positions that with further development can lead to potential future developments, sometimes long into the future [Ashton, Sen, $1988,1989] .^{3}$ Patent positions are usually integrated with other technology to produce improved processes or new product developments. Analysis uses a mixture of methodologies to find a relationship between the pieces of information, then synthesize this information to draw inferences from the relationships. It is important for analysts to protect themselves against biases and mistaken assumptions that are built into "mental models" or "mind sets" that we all have to assimilate and evaluate our experience of the world

\section{Table 12. Secondary Sources}

\begin{tabular}{|c|c|}
\hline Category & Items \\
\hline $\begin{array}{l}\text { Internal } \\
\text { Literature }\end{array}$ & $\begin{array}{l}\text { - Corporate documents } \\
\text { - Previous TI reports } \\
\text { - TI databases (literature, reports, etc.) } \\
\text { - Trip and contact reports } \\
\text { - Email } \\
\text { - Market assessments } \\
\text { - R\&D plans } \\
\text { - Proposals } \\
\text { - R\&D/Technology Staff reports } \\
\text { - Sales Force reports } \\
\text { - Purchasing/Procurement documents } \\
\text { - Regulatory/Legal documents } \\
\text { - Manufacturing descriptions }\end{array}$ \\
\hline $\begin{array}{l}\text { External } \\
\text { Distributed } \\
\text { Literature }\end{array}$ & $\begin{array}{l}\text { - Technical journals } \\
\text { - Patents } \\
\text { - Annual Reports } \\
\text { - Reports, studies } \\
\text { - News - press, newsletters } \\
\text { - Conference Exhibits } \\
\text { - Special information - employment ads }\end{array}$ \\
\hline Internet & $\begin{array}{l}\text { - Websites } \\
\text { - Chat Rooms }\end{array}$ \\
\hline $\begin{array}{l}\text { External Grey } \\
\text { Literature }\end{array}$ & $\begin{array}{l}\text { - Company reports, brochures } \\
\text { - Dissertations/theses } \\
\text { - Trade or product literature } \\
\text { - Government documents } \\
\text { - Working papers } \\
\text { - White papers }\end{array}$ \\
\hline
\end{tabular}




\section{Table 13. Technical Sources}

\begin{tabular}{|l|l|}
\hline \multicolumn{1}{|c|}{ Category } & \multicolumn{1}{c|}{ Items } \\
\hline Remote Sensing & $\begin{array}{l}\bullet \text { Remote Imagery and film } \\
\text { - Still \& Motion Photography } \\
\text { Chemical, Electromagnetic, Radiological } \\
\text { or Chromatic Emissions }\end{array}$ \\
\hline $\begin{array}{l}\text { Technical } \\
\text { Databases }\end{array}$ & $\begin{array}{l}\bullet \text { Technical Associations } \\
\text { University Programs } \\
\text { Government S\&T Laboratories (National } \\
\text { and State) }\end{array}$ \\
\hline $\begin{array}{l}\text { Reverse } \\
\text { Engineering }\end{array}$ & $\begin{array}{l}\text { Equipment } \\
\text { Business Practices }\end{array}$ \\
\hline Source: author. & \\
\hline
\end{tabular}

[Krizan, 1999]. A systematic approach to analysis that explicitly considers a range of alternative explanations and outcomes offers one way to guard against dismissing potentially relevant hypotheses and supporting information - which can lead to missed opportunities to assess or warn. To complicate matters, there are few standard ways to perform such analysis, while a wide range of approaches and tools are available.

\section{TI Analysis Techniques and Tools}

Effective intelligence analysis incorporates elements of three families of techniques:

- diagnostic techniques that are primarily aimed at establishing the transparency of analytic arguments, assumptions, or intelligence gaps;

- contrarian techniques that explicitly challenge current thinking and approaches;

- imaginative thinking techniques like "brainstorming" that aim to develop new insights, different perspectives, and/or alternative outcomes.

A variety of computerized information analysis tools are used by TI practitioners to help organize, evaluate, and conduct various analysis processes on information for intelligence uses. One well-known source contains a systematic evaluation of several dozen such tools used in science, technology, and innovation (STI), other intelligence problems, and many other technol- ogy analysis applications [Fleisher, Bensoussan, 2002; Fleisher, 2006].

Several popular examples that focus on technology characteristics, companies, and innovative developments are listed in Table 15. Discussing these methods is beyond the scope of this paper, but many sources describing them are available. Experience demonstrates there is no single tool or technique that can fully address the range of common S\&T analysis tasks. Analysts will also need to understand which combinations of tools and techniques can be most effective in meeting particular kinds of critical intelligence needs [Herring, 1999]. The application of a combination of tools over the course of producing the intelligence is usually required; understanding what sequence of techniques will be most effective is usually challenging.

\section{Step 4: TI Production \& Reporting}

Technology intelligence is deliberately produced; it is not just passively collected. This means that the data and analysis outputs described are evaluated, integrated, and interpreted by skilled TI practitioners. As a practical matter, intelligence production refers to creating finished briefings or reports for decision makers or other customers. The emphasis in production is the synthesis of "all source" intelligence inputs to produce a comprehensive assessment of an intelligence problem situation. For example, in the private sector, input data may be produced from library or online research specialists, HUMINT staff who conduct interviews and attend conferences and trade shows, or for technology intelligence, engineers or scientists who perform work on products, design or product-related materials. These specialists would forward their reports to a centralized intelligence body that produces a synthesized finished intelligence product for the customer using all available inputs. One main aspect of intelligence production is the preparation of a "Bottom Line Up Front" (BLUF) statement as part of the deliverable - one that presents the overall conclusion in a clear, concise way that is easily understood by the customers. This is part of what intelligence professionals deliver as their response

\section{Table 14. Processing and Examples of Data Collation}

\begin{tabular}{|l|l|}
\hline Data processing & $\begin{array}{l}\text { integrating, arranging, and annotating related information; } \\
\text { evaluating the accuracy and reliability of each item; } \\
\bullet \text { grouping items into logical categories; } \\
\bullet \text { critically examining the information source; } \\
\bullet \text { assessing the meaning and usefulness of the content for further analysis - including some effort to draw } \\
\text { tentative conclusions about the relationship of «facts" to each other and their significance; } \\
\text { - identifying information gaps to guide further data collection and analysis and providing a framework for } \\
\text { selecting and organizing additional information. }\end{array}$ \\
\hline $\begin{array}{l}\text { Data collation } \\
\text { examples }\end{array}$ & $\begin{array}{l}\text { - filing documents; } \\
\text { statistical analysis; } \\
\text { network evaluation; } \\
\text { data analytics and visualization; } \\
\text { condensing information by categories or relationships; } \\
\text { using electronic database programs to store, sort, and arrange large quantities of information or data in } \\
\text { planned or dynamically established patterns. }\end{array}$ \\
\hline Source: own elaboration based on [Krizan, 1999].
\end{tabular}


Table 15. Popular Analysis Techniques and Tools

\begin{tabular}{|l|l|l|l|}
\hline No & \multicolumn{1}{|c|}{ Method } & No & \multicolumn{1}{c|}{ Method } \\
\hline 1 & $\begin{array}{l}\text { Analysis of Competing } \\
\text { Hypotheses }\end{array}$ & 10 & Scenario Analysis \\
\hline 2 & Linchpin Analysis & 11 & Scientometrics \\
\hline 3 & Benchmarking & 12 & Shadowing \\
\hline 4 & $\begin{array}{l}\text { Disruptive Technology } \\
\text { Assessments }\end{array}$ & 13 & Strategic Relationships \\
\hline 5 & Driving Forces & 14 & SWOT \\
\hline 6 & $\begin{array}{l}\text { Event and Timeline } \\
\text { Analysis }\end{array}$ & 15 & Technology Forecasting \\
\hline 7 & Indications and Warnings & 16 & Technology Scenarios \\
\hline 8 & $\begin{array}{l}\text { Literature Mapping and } \\
\text { Bibliometrics }\end{array}$ & 17 & Trend Analysis \\
\hline 9 & Patent Analysis & 18 & Foresight Studies \\
\hline Source: author. & \multicolumn{3}{|l}{} \\
\hline
\end{tabular}

to the original intelligence problem and the specific intelligence needs that drove the process. Intelligence is rarely as complete as the customers would like. It usually consists of information fragments, analyst estimates, and judgments to support the main findings and key messages. However, these must be persuasive to justify the action recommendations, since following these will consume time and resources that the organization must supply. This production phase should include some "reality checking" to ensure that the messages and back-up materials make sense.

\section{Step 5: Delivery \& Feedback}

Once the finished intelligence is developed and finalized, it must be delivered to the customers to "close the loop" and debrief the process. The main aspects of this step include messaging, customer feedback discussions, and follow-up support. It is important for TI products to use delivery mechanisms and formats that are appropriate for the overall messages and that address the original customer needs and dissemination preferences. Delivery approaches range from formal reports or presentations to electronic mail and one-onone conversations, tailored to meet customer preferences. Several options for packaging the TI results are shown in Table 16.

Many TI professionals believe that a face-to-face presentation and discussion is the best approach for most delivery processes - with suitable backup documentation. This format enables customer feedback comments, which are crucial to assess the intelligence value, discuss follow-up actions and develop suggestions for improvement. Discussion with customers after products have been delivered will enable continuing intelligence to be provided as needed, integration with other inputs, and a check on cross-cutting issues or values that were not apparent early in the process. Many customers will want more than just the BLUF, so the intelligence team

\section{Table 16. Options for Packaging the TI Results}

\begin{tabular}{|c|c|}
\hline Type & Items \\
\hline In Person & $\begin{array}{l}\text { - Personal sit-down meetings } \\
\text { - Briefings } \\
\text { - Seminars, retreats } \\
\text { - Working groups }\end{array}$ \\
\hline $\begin{array}{l}\text { Distant contact / } \\
\text { correspondence }\end{array}$ & $\begin{array}{l}\text { - Email } \\
\text { - Groupware } \\
\text { - Internet posting } \\
\text { - Newsletters } \\
\text { - Trip reports } \\
\text { - Contact memos } \\
\end{array}$ \\
\hline Documentation & $\begin{array}{l}\text { - Reports } \\
\text { - Action Plans } \\
\text { - Videos } \\
\text { - Still photography } \\
\text { - Diagrams } \\
\text { - Chemical emissions data }\end{array}$ \\
\hline Source: author. & \\
\hline
\end{tabular}

must be prepared to present the evidence and rationale for the findings and recommendations. This material should include a discussion of the quality of sources and source material, and judgements about "analytic confidence" - rating statements about what is known with high (and low) confidence - to convey doubt to customers, especially about estimative probabilities. This reflects the imperfect state of knowledge and limitations of the conceptual models used in the situation. Finally, the messages are more persuasive when coming from analysts that have high credibility and when being presented consistently from different sources because messages can be ambiguous if they are interim, based on assumed scenarios, and still under development [Lichtenthaler, 2007; Rohrbeck et al., 2006; Önkal et al., 2013] and therefore seem inadequate to cover all the situations.

\section{TI Project Example - An Unsuccessful Equipment Offering}

To illustrate major elements of a TI project, a published example case study from Air Products \& Chemicals, Inc. (APC) is summarized in this section [Brenner, 2009]. The discussion is presented in a structured, comprehensive format, with headings that incorporate and fit into the five main intelligence process steps of TI projects as presented in this paper. The discussion concludes with an explanation of the benefits of the project for APC.

Intelligence Problem: The TI group at APC was approached by a business unit to do an analysis of an APC equipment offering on the industrial gas supply market vs competitor offerings. Industrial gas technology involves equipment to gather, clean, pressurize, measure, store, and distribute industrial gas. The APC business group thought that the APC product development organization had come up with a superior offering, but the product was not selling well. 
Table 17. Factors Covered by the Example TI Study

\begin{tabular}{|l|l|l|l|}
\hline No & \multicolumn{1}{|c|}{ Item } & No & \\
\hline 1 & Cost & 14 & Geographical coverage \\
\hline 2 & Performance & 15 & Customer loyalty \\
\hline 3 & Differentiated technology & 16 & Marketing skills \\
\hline 4 & Speed & 17 & Coordinated/integrated approach across company \\
\hline 5 & Breadth of offering & 18 & Customer focus \\
\hline 6 & Flexibility & 19 & Customer service \\
\hline 7 & Economies of scale & 20 & Distribution \\
\hline 8 & Innovative programs/services & 21 & Downtime \\
\hline 9 & Availability of new products/services & 22 & Ability to deliver on time \\
\hline 10 & Market position & 23 & Competition \\
\hline 11 & Marketing mix, e.g., breadth/depth, complements & 24 & Technology changes \\
\hline 12 & Quality reputation & 25 & Industry structural changes \\
\hline 13 & Service reputation & 26 & $\begin{array}{l}\text { Value added to products/ services, e.g., special warranties, extra } \\
\text { customer care }\end{array}$ \\
\hline Source: author. & & \\
\hline
\end{tabular}

\section{Step 1: Customer TI Needs Assessment}

Customer TI Assignment: The TI group was assigned to help determine whether APC should continue with the current offering or implement modifications, which would likely require a continuing product development project.

TI Requirement: The group was assigned to assess each competitor based on key factors that determine new product success on the industrial gas market and compare them to each other and APC.

TI Project Scope: The TI group began by scoping the project work - identifying competitors and market success factors. Company experience indicated that many factors contribute to the success of a new product offering on the target industrial gas market. The team developed an extensive list of relevant factors shown in Table 17.

This original factor list was narrowed to a manageable number by reviewing similar projects from the recent past. The discussions included an important debate between the TI and business groups at APC about the relative importance of these criteria when setting the priorities. This illustrates the point that substantive issues can arise during interaction between technical and marketing groups to potentially complicate TI project work. APC was able to work through these issues successfully.

\section{Step 2: TI Collection and Processing}

External Search strategy: An online, HUMINT, patent, and document search plan was developed to describe each competitor's position on each of the final factors. Based on initial broad searching and internal APC discussions, the TI group identified a final set of key factors for success in their target marketplace. This included knowledge and perspectives of both the APC commercial and technology groups for this product area. Different perspectives were raised during these discussions regarding whether this product was a technology or commercial "failure".

Search process results: The external searching brought objectivity and balance to the internal group biases. The search process expanded the team's knowledge about each competitor's position on each factor, including what APC competitors' thought were the keys to their success as well.

\section{Step 3: TI Analysis and Synthesis}

Analysis Preparation: To prepare for the equipment offering data analysis, the group completed a Background Package to integrate what was discovered and focus on the factors determined to be most important for market success. This involved the consideration of other internal information and included the flexibility to adjust the factor priorities during the review.

Analysis Process: To analyze the data on each competitor, the group planned a SWOT analysis to tabulate what we had found for each criterion and each competitor, including APC. The SWOT seemed like a good fit for the problem as it was likely to generate the strategies for change that would be needed (see Table 18). This method revealed gaps in the team's knowledge that were continually addressed throughout the analysis session.

\section{Step 4: TI Production \& Reporting}

TI Findings: As the team discussed and came to an agreement upon the strengths, weaknesses, opportu- 


\section{Table 18. SWOT Format Guiding Strategy} Development

\begin{tabular}{|l|l|l|}
\hline & \multicolumn{1}{|c|}{ Internal Strengths } & Internal Weaknesses \\
\hline $\begin{array}{l}\text { External } \\
\text { Opportunities }\end{array}$ & $\begin{array}{l}\text { S-O Conclusions and } \\
\text { Strategies }\end{array}$ & $\begin{array}{l}\text { W-O Conclusions } \\
\text { and Strategies }\end{array}$ \\
\hline $\begin{array}{l}\text { External } \\
\text { Threats }\end{array}$ & $\begin{array}{l}\text { S-T Conclusions and } \\
\text { Strategies }\end{array}$ & $\begin{array}{l}\text { W-T Conclusions } \\
\text { and Strategies }\end{array}$ \\
\hline Source: [Brenner, 2009].
\end{tabular}

nities, and threats, the nature of the "failure" changed dramatically. Although the APC technology was considered to have differentiating characteristics, the customers interviewed found it to be roughly equivalent to the competitive offerings. Also, the analysis highlighted critical problems in the APC effort - that the APC business offering was late to the market, had missed the dominant customer, had far inferior marketing and visibility, and also, somewhat surprisingly, featured unclear roles within the APC business team due to overlapping or unassigned responsibilities.

Identify Candidate Follow-up Actions: The team then used the SWOT process to create four mini-scenarios that addressed how APC should deal with the situation. Then, using the scenarios, the team selected action strategies that worked for multiple scenarios. It was clear that the business had many significant actions to pursue.

\section{Step 5: Delivery \& Feedback}

Recommendations and Results: The team's recommendations included short-term milestones for both product modifications and marketing process adjustments, which were required for keeping the offering worthwhile. The recommended actions were pursued, but the milestone objectives were not achieved and the product offering was eventually abandoned.

TI group concerns: An interesting issue arose during a review of the project. The TI group project was being funded by the business organization that now appeared to be responsible for the problems. However, since everyone arrived at these conclusions together and since the SWOT generated actionable changes, the business staff were pleased with the results because they had clear evidence with which to now deal with many business development issues that had previously been difficult to define and reconcile.

TI Benefits: Due to the TI analysis, APC avoided continuing a development program to improve the technology, which would not have significantly changed their market position, and thereby prevented inappropriate efforts to continue promoting the offering. The result was significant savings of potentially wasted time and new product costs.

\section{Conclusions}

This paper has presented an overview of the basic features and current practices for the development and use of technology intelligence as applied in many private and government organizations. TI includes wide area surveillance and scanning to monitor technology landscapes as well as focused TI collection to assess or track specific technologies, R\&D efforts, companies, or industry groups. Strong growth of TI in professional literature over the past several years strongly suggests that TI has provided real business value to the organizations that employ it.

Most businesses are aware of the main technology and market developments in their direct markets and areas of interest. However, new and disruptive developments usually arise from outside their field of view - from an area which would not normally be a focus of their corporate radar. Moreover, new developments are often not just a single technology, but emerge from combinations of new capabilities, often from unforeseen directions. As described in this article, these situations call for some form of an organized TI process that can connect the dots and assess the impact that an emerging technology may have on existing business assets and prospects.

This overview points out the three important areas of TI focus: early warning of threats and opportunities to avoid surprises, assessments of current players on relevant markets and along supply chains, and longrange insights for support of strategic planning and strategy development. A well-supported TI program with trained staff can take advantage of either near- or long-term developments in these areas to help position organizations for healthy growth and operations well into the future. TI, however, must have organizational support to remain a viable activity - not only from senior managers, but from regular customers, information professionals, and analytical specialists. The quality of relations between the TI staff and these organizational groups is a key element of ensuring longterm TI success. This means that the TI staff must seek feedback from others in the organization, evaluate their own performance, and constructively respond to what they learn. Many CI and TI units have eventually been shut down as a cost saving measure if these practices are not maintained. The pace and direction of TI growth is difficult to assess and predict. What is clear is that future business leaders will continue to apply technology as a core element of their business strategy and operations, which makes TI an important continuing business practice. Organizations will always need accurate, focused, and timely technology information to take advantage of technology opportunities and prevent technology-based disruptions by competitors and new players. The payoff from effective TI is a much better chance of long-term business success in their chosen marketplaces. 


\section{References}

Ashton W.B., Sen R.K. (1988) Using Patent Information in Technology Business Planning. Research-Technology Management, vol. 31, no 6, pp. 42-46.

Ashton W.B., Klavans R.A. (eds) (1997) Keeping Abreast of Science and Technology: Technical Intelligence for Business, Columbus, OH: Battelle Press.

Ashton W.B., Sen R.K. (1989) Using Patent Information in Technology Business Planning - II. Research-Technology Management, vol. 32, no 1, pp. 36-42.

Ashton W.B., Stacey G.S. (1995) Technical Intelligence in Business: Understanding Technology Threats and Opportunities. International Journal of Technology Management, vol. 10, no 1, pp.79-104.

Brenner M. (2009) Evolving Technology Intelligence into Decision Support. Competitive Technical Intelligence (eds. W.B. Ashton, B. Hohhof), Alexandria, VA: Competitive Intelligence Foundation, pp. 29-45.

Buzzanga J. (2008) Using Technology Intelligence for R\&D. Industry Week, 03.09.2008. Available at: http://www. industryweek.com/articles/using_technology_intelligence_for_rd_17162.aspx, accessed 15.04.2019.

Calof J., Richards G., Smith J. (2010) The Integrative Domain of Foresight and Competitive Intelligence and Its Impact On R\&D Management. R\&D Management, vol. 40, no 1, pp. 31-39.

Calof J., Richards G., Smith J. (2015) Foresight, Competitive Intelligence and Business Analytics - Tools for Making Industrial Programmes More Efficient. Foresight and STI Governance, vol. 9, no 1, pp. 68-81.

Das S. (2020) Competitive Technical Intelligence Tools for Innovation and Technology Forecasting. Asia Pacific Business Review, vol. 6, no 2, pp. 30-40.

DoD (2004) Field Manual No. 2 - Intelligence, Washington, D.C.: Department of Defence.

Fleisher C.S., Bensoussan B. (2002) Strategic and Competitive Analysis: Methods and Techniques for Analyzing Business Competition (1st ed.), Upper Saddle River, NJ: Prentice Hall.

Fleisher C., Ashton B. (2009) A Tripartite Early Warning Capability for the Technologically-based Enterprise. Competitive Technical Intelligence (eds. W.B. Ashton, B. Hohhof), Alexandria, VA: Competitive Intelligence Foundation, pp. 95-110.

Fleisher C. (2006) Assessing the tools and techniques enterprises use for analyzing Innovation, Science and Technology (IS\&T) factors: Are they up to the task? International Journal of Technology Intelligence and Planning, vol. 2, no 4, pp. 380-405.

Herring J. (1999) Key Intelligence Topics: A Process to Identify and Define Intelligence Needs. Competitive Intelligence Review, vol. 10,no 2, pp. 4-14.

Heuer R.J. (Jr.) (1999) The Psychology of Intelligence Analysis, Washington, D.C.: Center for the Study of Intelligence.

Krizan L. (1999) Intelligence Essentials for Everyone, Washington, D.C.: Joint Military Intelligence College.

Lichtenthaler E. (2007) Managing technology intelligence processes in situations of radical technological change. Technological Forecasting and Social Change, vol. 74, no 8, pp. 1109-1136.

Manzini P., Mariotti M. (2009) Choice over Time. Oxford Handbook of Rational and Social Choice (eds. P. Anand. P. Pattnaik, C. Puppe), New York: Oxford University Press, pp. 239-270.

Manzini R., Nasullaev A. (2017) Technology Intelligence in Practice, Castellanza VA (Italy): Università Cattaneo.

Mogee M.E., KolarR.G.(1999) PatentCo-Citation Analysis ofEliLilly \&Co.ExpertOpinionon TherapeuticPatents, vol.9, no3, pp. 291-305.

Mortara L., Kerr C., Phaal R., Probert D. (2007) Technology intelligence: Identifying threats and opportunities from new technologies, Cambridge (UK): University of Cambridge. Available at: https://www.ifm.eng.cam.ac.uk/insights/ technology-strategy/technology-intelligence/, accessed 03.06.2020.

Mortara L., Kerr C., Phaal R., Probert D. (2009) Technology intelligence practice in UK technology-based companies. International Journal of Technology Management, vol. 48, no 1, pp. 115-135.

Mortara L. (2015) Communicating intelligence. Paper presented at the XXVI ISPIM Innovation Conference, June 14-17, Budapest, Hungary.

Mortara L., Thomson R., Moore C., Armara K., Kerr C.I., Phaal R., Probert D.R. (2010) Developing a technology intelligence strategy at Kodak European research: Scan \& target. Research-Technology Management, vol. 53, no 4, pp. 27-38. 
Nadarajah M. (2009) CTI and Technology Mapping for Strategic Decision Making. Keeping Track of Science and Technology: Technology Intelligence in Business (eds. W.B. Ashton, R. Klavans), Columbus, OH: Battelle Press, pp. 134-151.

Naisbitt J. (1982) Megatrends: Ten New Directions Transforming Our Lives, New York: Warner Books.

Norling P., Herring J., Rosenkrans W. (Jr.), Stellpflug M. (2000) Putting Competitive Technology Intelligence to Work. Research-Technology Management, vol. 43, no 5, pp. 23-28.

Önkal D., Sayim K.Z., Gönül M.S. (2013) Scenarios as channels of forecast advice. Technological Forecasting and Social Change, vol. 80, no 4, pp. 772-788.

Rohrbeck R. (2007) Technology Scouting - A Case Study on the Deutsche Telekom Laboratories. Paper presented at the ISPIM-Asia 2007 Conference, January 9-12 2007, New Delhi, India.

Rohrbeck R., Heuer J., Arnold H.M. (2006) The Technology Radar — an Instrument of Technology Intelligence and Innovation Strategy. Proceedings of the 3rd IEEE International Conference on Management of Innovation and Technology, June 21, 2006, Singapore, Piscataway, NJ: IEEE, pp. 978-983.

Rohrbeck R., Arnold H.M., Heuer J. (2007) Strategic Foresight in Multinational Enterprises - A Case Study on the Deutsche Telekom Laboratories. Paper presented at the ISPIM-Asia 2007 Conference, January 9-12, 2007, New Delhi, India, pp. 1-12.

Tessun F. (2007) Scenario Analysis and Early Warning Systems at Daimler-Benz aerospace. Competitive Intelligence Review, vol. 8, no 4, pp. 30-40.

Veugelers M., Bury J., Stijn V. (2010) Linking technology intelligence to open innovation. Technological Forecasting and Social Change, vol. 77, no 2, pp. 335-343. DOI:10.1016/j.techfore.2009.09.003. 